\title{
Sphaerothecum destruens pathology in cyprinids
}

\author{
D. Andreou ${ }^{1,2, *}$, R. E. Gozlan ${ }^{3}$, D. Stone ${ }^{4}$, P. Martin ${ }^{4}$, K. Bateman ${ }^{4}$, S. W. Feist ${ }^{4}$ \\ ${ }^{1}$ School of Biosciences, Cardiff University, Cardiff CF10 3XQ, UK \\ ${ }^{2}$ Centre for Ecology and Hydrology, Oxford OX1 3SR, UK \\ ${ }^{3}$ School of Applied Sciences, Bournemouth University, Poole BH12 5BB, UK \\ ${ }^{4}$ Cefas Weymouth Laboratory, Weymouth DT4 8UB, UK
}

\begin{abstract}
Sphaerothecum destruens is a significant intracellular parasite of fish which has caused disease and mortalities in cultured north American Chinook salmon Oncorhynchus tshawytscha and Atlantic salmon Salmo salar. Several hosts for $S$. destruens have been identified within the Salmonidae family, and the histopathology of the infection can differ between hosts. Recently, $S$. destruens has been associated with the most invasive cyprinid species in Europe, topmouth gudgeon Pseudorasbora parva. Accurate disease identification based on thorough descriptions of clinical signs and histopathology in this new range of hosts is thus paramount to support further epizootiological studies. In this study, the associated histopathology of $S$. destruens infection is described along with its pathogenesis in the endangered cyprinid sunbleak Leucaspius delineatus. Histological examination of $100 \mathrm{~L}$. delineatus in a wild population in the south of England revealed the presence of $S$. destruens infections, with a prevalence of $5 \%$ with $S$. destruens, suggesting an over-dispersed distribution within the L. delineatus sample. Clinical signs of the infection were absent, but histological examination revealed the presence of both disseminated and nodular lesions in several organs.
\end{abstract}

KEY WORDS: Fish $\cdot$ Salmonid $\cdot$ Invasive species $\cdot$ Europe $\cdot$ North America $\cdot$ Sunbleak

\section{INTRODUCTION}

Sphaerothecum destruens is a unicellular eukaryotic parasite of fish which has caused disease and mortalities up to $80 \%$ in north American Chinook salmon Oncorhynchus tshawytscha (Walbaum) and chronic mortalities in cultured salmon Salmo salar (L.) (Elston et al. 1986, Harrell et al. 1986, Hedrick et al. 1989, Arkush et al. 1998). Numerous potential hosts for $S$. destruens have been identified through experimental infections, including coho salmon $O$. kisutch (Walbaum), rainbow trout O. mykiss (Walbaum), brown trout Salmo trutta and brook trout Salvelinus fontinalis (Mitchill) (Arkush et al. 1998). It has recently been associated with the most invasive fish species in Europe, topmouth gudgeon Pseudorasbora parva (Temminck and Schlegel) (Gozlan et al. 2005, Andreou et al. 2010), which acts as a healthy carrier of $S$. destruens. Since then, a wide range of susceptible cyprinid hosts have been identified, such as sunbleak Leucaspius delineatus (Heckel), fathead minnow Pimephales promelas (Rafinesque) and bream Abramis brama (L.) (Andreou 2010).

Leucaspius delineatus has experienced major declines in its native range since the invasion of Pseudorasbora parva in the early 1960s and was listed on the International Union for Conservation of Nature (IUCN) Red List of Threatened Species (WCMC 1996). In 2008, it was listed as a species of least concern (Freyhof \& Kottelat 2008). L. delineatus originates from continental Europe and Russia and is distributed from the Caspian Sea to the North Sea, and from the Volga to Britany, France; it was accidentally introduced into the UK in 1986 at a commercial fishery in southern England and has since spread to the entire Bridgewater canal and River Rue catchment (Gozlan et al. 2003). The rapid dispersal of $L$. delineatus in England has been facilitated by its life 
history traits, such as its reproductive behaviour (batch spawning and male parental care), early sexual maturity and small adult size (Gozlan et al. 2003).

Following cohabitation between Pseudorasbora parva and Leucaspius delineatus (fish shared water but did not come in direct contact), $67 \%$ of emaciated moribund $L$. delineatus and $28 \%$ of non-moribund $L$. delineatus were found to be positive for Sphaerothecum destruens (Gozlan et al. 2005). When incubated in freshwater, $S$. destruens spores release numerous motile zooflagellate stages which show tolerance to a wide range of temperatures and which have a long life span (Andreou et al. 2009). An association of a multi-host parasite, such as $S$. destruens, with wild L. delineatus would potentially increase the risk of $S$. destruens spreading and would facilitate its introduction to new naïve native species (Gozlan et al. 2009, Peeler et al. 2011).

The pathology of Sphaerothecum destruens, described in detail for Oncorhynchus tshawytscha and Salmo salar (Arkush et al. 1998), includes 2 forms of host response: disseminated and nodular (Arkush et al. 1998). In the former, $S$. destruens spores and developmental stages are widely dispersed throughout the host with little apparent host cell response (Elston et al. 1986). In contrast, the nodular form of the disease is characterised by a chronic inflammatory response with the formation of distinct granulomas in visceral organs (Hedrick et al. 1989, Arkush et al. 1998).

Pathology can differ in hosts belonging to different families (Arkush et al. 1998) and the potential for misdiagnosis exists. Accurate identification based on pathogen identification and thorough descriptions of histopathology is consequently paramount to support epizootiological studies for Sphaerothecum destruens as well as for other parasitic infections (Bucke et al.1991, Feist \& Longshaw 2008). Naturally occurring infections in Leucaspius delineatus have not been described. Here, we present the first record of $S$. destruens in wild populations of $L$. delineatus along with its associated histopathology. In light of the endangered status of $L$. delineatus, the discovery of naturally occurring $S$. destruens infections in an established UK $L$. delineatus population provides important new information on the pathogenesis and potential impact of S. destruens on L. delineatus throughout Europe.

\section{MATERIALS AND METHODS}

Samples. A population of Leucaspius delineatus in the Stoneham Lakes system, Hampshire, UK $\left(50^{\circ} 57^{\prime} 14^{\prime \prime} \mathrm{N}, 1^{\circ} 22^{\prime} 48^{\prime \prime} \mathrm{W}\right)$ was sampled at the end of January 2006. In total, 978 individual fish (average weight $1.5 \mathrm{~g}$ ) were caught by seine netting. Upon arrival at the laboratory, fish were kept in a flow- through system at $9^{\circ} \mathrm{C}$. A total of $90 \mathrm{~L}$. delineatus were immediately euthanized with an overdose of methane tricaine sulphonate (MS-222, Sigma-Aldrich) and processed for molecular detection of Sphaerothecum destruens using the polymerase chain reaction (PCR). Due to the limited quantity of tissue available from these fish, no tissue was taken for histological examination or electron microscopy. The remaining fish were kept at $9.0^{\circ} \mathrm{C}$ in a flow-through system for $6 \mathrm{wk}$. At the end of this period the water temperature was raised to $15.0^{\circ} \mathrm{C}$ at a rate of $1.5^{\circ} \mathrm{C} \mathrm{d}^{-1}$ and was maintained at $15.0^{\circ} \mathrm{C}$ for a further $6 \mathrm{wk}$. At the end of this period $100 \mathrm{~L}$. delineatus were sampled and tested for $S$. destruens by PCR. One month later, 100 fish were processed specifically for histopathology and electron microscopy. In addition, during the course of this trial, the periodic bagging and freezing of $L$. delineatus mortalities was undertaken. This resulted in the collection of an additional 6 deceased L. delineatus, which were also tested for $S$. destruens by PCR only.

DNA extraction. Kidney and liver tissue samples were pooled together (approximately $0.05 \mathrm{~g}$ ) for each fish and were physically disrupted and then digested overnight at $56^{\circ} \mathrm{C}$ in a $0.5 \mathrm{ml}$ volume using Proteinase $\mathrm{K}$. DNA was extracted from $50 \mu \mathrm{l}$ of the digested material with DNAzol (Invitrogen) using the manufacturer's recommended protocol. The pellet was then dissolved in $40 \mu \mathrm{l}$ RNase/DNase-free water (BDH).

PCR and sequence analysis. All samples were subjected to a nested PCR assay employing the Sphaerothecum destruens-specific primers 5'-AAT CGT ATG ACA TTT TGT CGA C-3' and 5'-GAA GTC ACA GGC GAT TCG G-3' in the first round of the PCR, and an internal primer set 5'-ACA GGG CTT TTT AAG TCT TGT-3' and 5'-ATG GAG TCA TAG AAT TAA CAT $\mathrm{CC}-3^{\prime}$ in the second round (Gozlan et al. 2005). Fifty to $100 \mathrm{ng}$ of the DNA template was used in a $50 \mu \mathrm{l}$ reaction volume in the first round of amplification using standard cycling conditions of $94^{\circ} \mathrm{C}$ for $5 \mathrm{~min}$, then 35 cycles of $94^{\circ} \mathrm{C}$ for $1 \mathrm{~min}, 55^{\circ} \mathrm{C}$ for $1 \mathrm{~min}, 72^{\circ} \mathrm{C}$ for $1 \mathrm{~min}$ followed by a final extension step of $72^{\circ} \mathrm{C}$ for $10 \mathrm{~min}$. A $2.5 \mu \mathrm{l}$ sample of the first round product was used as a template in a $50 \mu \mathrm{l}$ reaction volume in the second round of amplification using the same cycling conditions. Post-PCR, all products were resolved on a $2 \%$ agarose gel, and products of the correct size were confirmed as $S$. destruens by sequence analysis.

Light microscopy. Tissues were fixed in $10 \%$ neutral buffered formalin (NBF) for $24 \mathrm{~h}$ before being transferred to $70 \%$ industrial methylated spirit (IMS). Samples were infiltrated with paraffin under vacuum using standard protocols. Sections were cut at a thickness of 3 to $5 \mu \mathrm{m}$, mounted onto glass slides, and stained with haematoxylin and eosin (H\&E) or Gram stain. Stained sections were analysed by light microscopy (Nikon 
Eclipse E800); digital images and measurements were obtained using the Lucia ${ }^{\mathrm{TM}}$ Screen Measurement System (Nikon). The prevalence of disease was calculated as (number of Sphaerothecum destruens-positive fish/ total number of fish tested) $\times 100$.

Electron microscopy. Small blocks $\left(2 \mathrm{~mm}^{3}\right)$ of tissue were fixed for electron microscopy in $2.5 \%$ glutaraldehyde in $0.1 \mathrm{M}$ sodium cacodylate buffer $(\mathrm{pH}$ 7.4) for $2 \mathrm{~h}$ at room temperature. Fixed tissue samples were rinsed in $0.1 \mathrm{M}$ sodium cacodylate buffer ( $\mathrm{pH}$ 7.4) and post-fixed for $1 \mathrm{~h}$ in $1 \%$ osmium tetroxide in $0.1 \mathrm{M}$ sodium cacodylate buffer. Specimens were washed in 3 changes of $0.1 \mathrm{M}$ sodium cacodylate buffer before dehydration through a graded acetone series. Specimens were embedded in Agar 100 epoxy (Agar Scientific, Agar 100 pre-mix kit medium) and polymerised overnight at $60^{\circ} \mathrm{C}$ in an oven. Semi-thin (1 to $2 \mu \mathrm{m}$ ) sections were stained with Toluidine Blue for viewing with a light microscope to identify suitable target areas. Ultrathin sections ( 70 to $90 \mathrm{~nm}$ ) of target areas were mounted on uncoated copper grids and stained with $2 \%$ aqueous uranyl acetate and Reynolds' lead citrate (Reynolds 1963). Grids were examined using a JEOL JEM 1210 transmission electron microscope, and digital images were captured with a Gatan Erlangshen ES500W camera and Gatan Digital Micrograph ${ }^{\mathrm{TM}}$ software.

\section{RESULTS}

\section{Prevalence of Sphaerothecum destruens in Stoneham Lakes}

Of the initial 90 fish sampled, 2 tested positive for Sphaerothecum destruens by PCR. From the second sampling, 1 fish out of 100 live fish and an additional 2 from the 6 natural mortalities tested positive for $S$. destruens by PCR, resulting in an overall prevalence of $2.8 \%$ by PCR. In addition, 5 out of the 100 Leucaspius delineatus sampled for detection via histology were positive for infection with $S$. destruens. Overall, the prevalence of $S$. destruens was determined by histology to be $5 \%$, and the kidney was parasitized in all 5 positive fish. Parasitized fish did not show any internal gross signs of disease and did not appear emaciated.

\section{Light microscopy}

Sphaerothecum destruens infection was systemic in Leucaspius delineatus, being observed in all vital organs, including the kidney, spleen, liver, intestine, gonad, eye, adipose tissue (surrounding the intestinal tract) and skeletal muscle. Both the disseminated and nodular disease morphologies were observed, with the former being most common $(80 \%$ of $L$. delineatus that were positive for $S$. destruens showed the disseminated form). Intense inflammation was observed in the testis and kidney (Fig. 1). Numerous stages of the organism's spore, with sizes ranging between 2 and $4 \mu \mathrm{m}$ in diameter, were observed within the tissues; most stages appeared to be intracellular (Fig. 2B). S. destruens was deeply eosinophilic with H\&E. However, individual $S$. destruens cells were often better discerned using Gram's stain whereby Gram-positive granules in the cytoplasm of $S$. destruens were prominent, even when in low numbers (Fig. 2A). In the disseminated form, parasites were present both intracellularly and extracellularly within infected tissues, and they formed rosettes, i.e. aggregates of closely apposed spores (Fig. 2B). Lesions varied in severity from intense (Fig. 3A) to those with minimal host cell response (Fig. 3C,D). S. destruens cells in the liver induced an inflammatory response involving mainly an influx of phagocytic cells (which frequently contained parasites), and there was some lymphocytic infiltration of the hepatic parenchyma (Fig. 3A). In ocular tissues, $S$. destruens cells were present within macrophages, and giant cell formation was observed (Fig. 3C). Multifocal granulomas of different sizes were detected in the testis and liver (Figs. 1A,B \& 3B). A range of granuloma stages were observed: from enlarged macrophage aggregates surrounded by a single-cell layer of connective tissue (Fig. 3B) to well-demarcated lesions surrounded by a thick fibroblast layer (Fig. 1B). In some cases granulomas replaced the normal parenchyma of these organs; these contained numerous single parasites as well as the typical parasite rosettes seen in salmonid infections. Affected testicular tissue was characterized by the presence of granulomas of different sizes, multifocal necrosis and intense inflammation (Fig. 1A,B). Several 'ghost' (unstained, dead) parasites were present within these granulomas and were seen in lower numbers in other tissues.

\section{Sphaerothecum destruens ultrastructure}

Parasites were located intracellularly in various types of host cell, including renal tubule and collecting-duct epithelial cells where they were associated with extensive vacuolar degeneration and necrosis. In established granulomatous lesions, stages of Sphaerothecum destruens were most frequently seen within macrophages and other phagocytic cells. Within the renal tissue of Leucaspius delineatus typical rosette clusters of $S$. destruens were only occasionally seen. More frequently, isolated spores in various stages of development were observed together with remnants of necrotic spores (Fig. 4A). Spores were uninucleate, containing 1 or 2 mitochondria and up to 10 spherical structures containing dense 

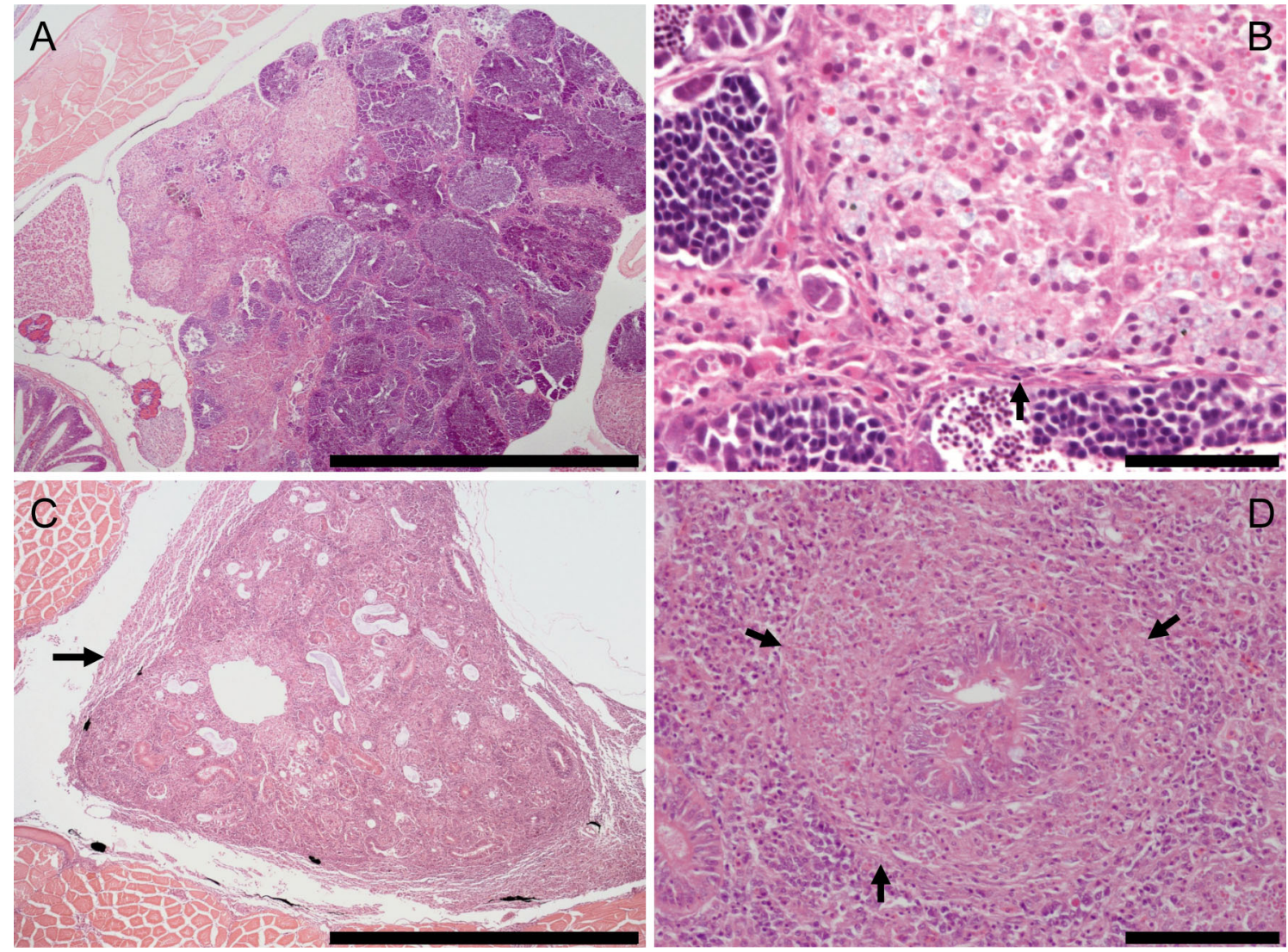

Fig. 1. Leucaspius delineatus. Light micrographs of tissue sections stained with haematoxylin and eosin from $L$. delineatus naturally infected with Sphaerothecum destruens. (A) Low magnification view of testis showing localised, multiple granulomas of different sizes. Scale bar $=1 \mathrm{~mm}$. (B) High magnification view of a granuloma in the testis. The granuloma is surrounded by a thin fibroblast layer (arrow). Within the granuloma there are numerous stages of $S$. destruens, cell necrosis, numerous 'ghost' (unstained dead) parasites, and macrophages. Scale bar $=50 \mu \mathrm{m}$. (C) Low magnification view of kidney. Note inflammation around the organ periphery (arrow). Scale bar $=1 \mathrm{~mm}$. (D) Intense inflammation surrounding a kidney tubule (arrows). Clusters of $S$. destruens are present within tubular epithelial cells. Scale bar $=100 \mu \mathrm{m}$
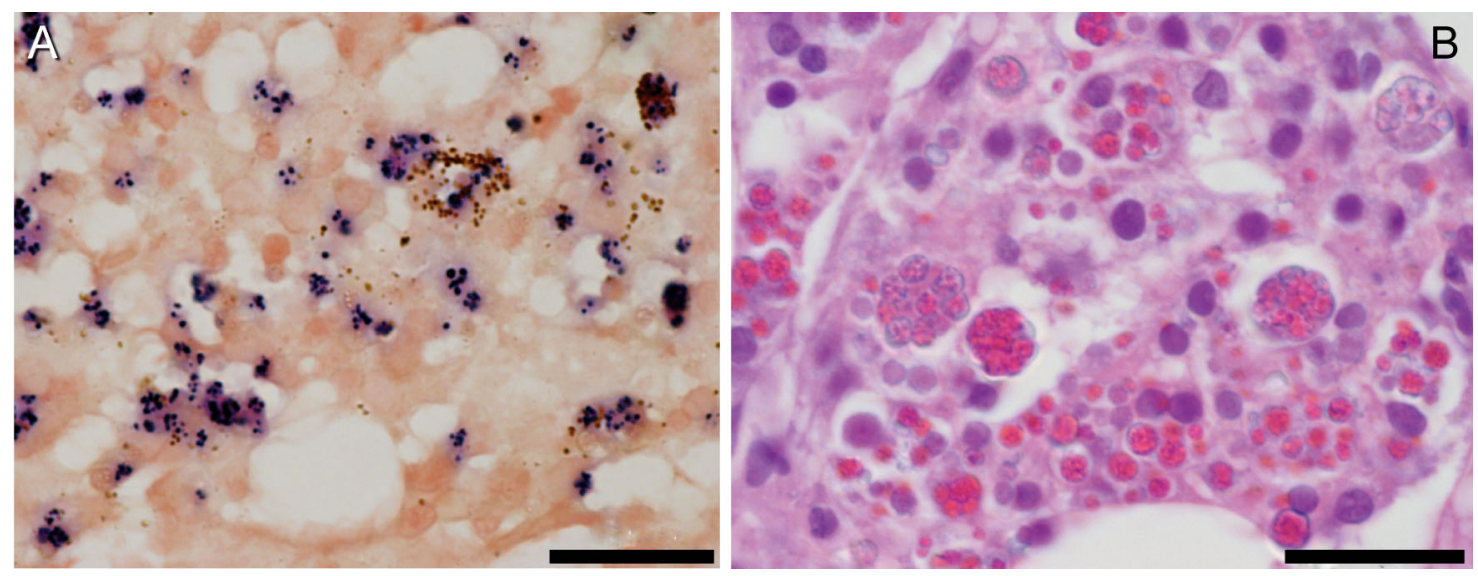

Fig. 2. Leucaspius delineatus. Light micrographs of tissue sections stained with (A) Gram's stain and (B) haematoxylin and eosin. (A) Liver tissue showing numerous Gram-positive granules within Sphaerothecum destruens cells. Scale bar $=20 \mu \mathrm{m}$. (B) High magnification view showing intracellular and extracellular $S$. destruens rosettes of different sizes. Scale bar $=20 \mu \mathrm{m}$ 

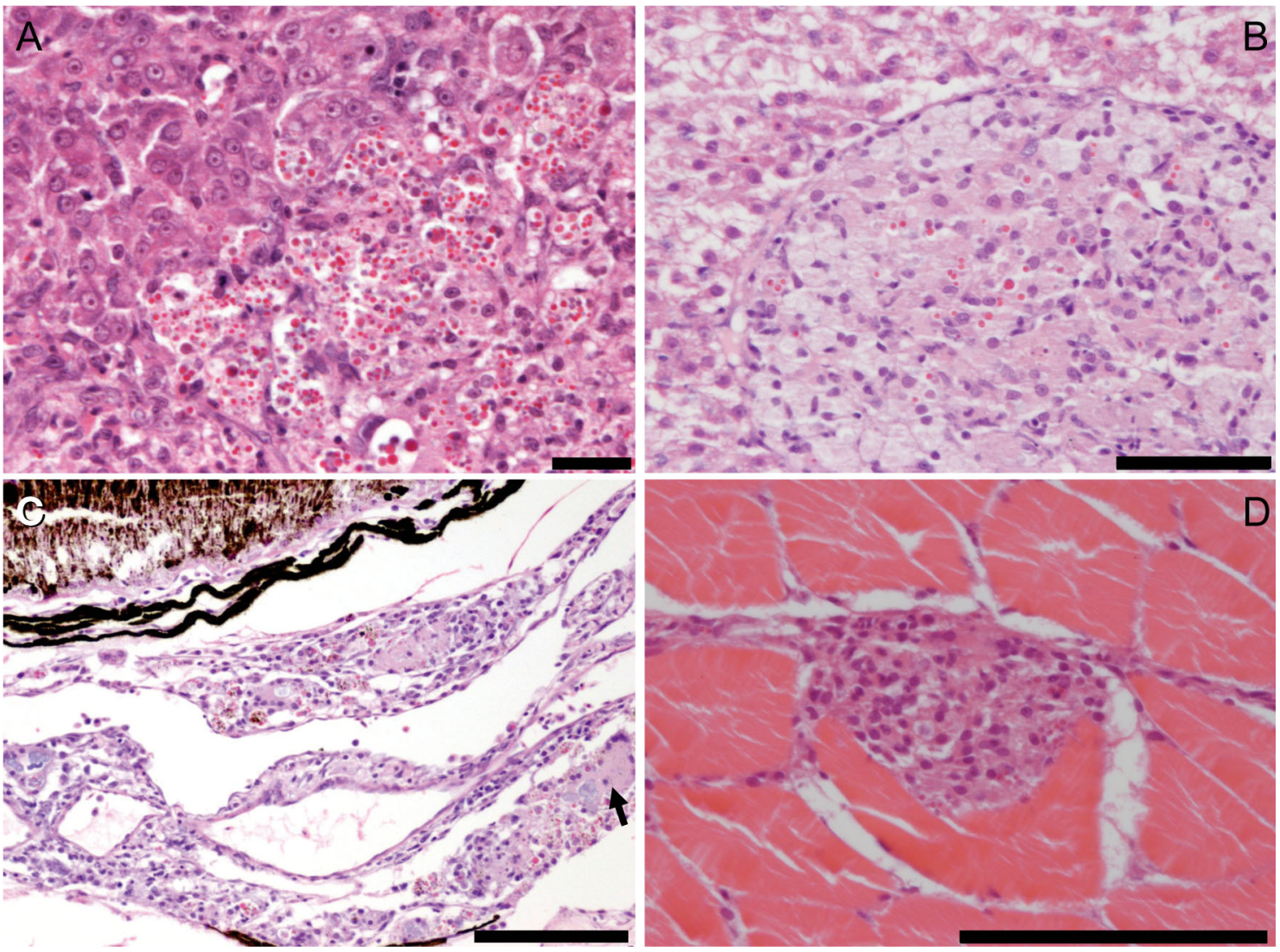

Fig. 3. Leucaspius delineatus. Light micrographs of tissue sections stained with haematoxylin and eosin from L. delineatus naturally infected with Sphaerothecum destruens. (A) Hepatic lesion associated with numerous $S$. destruens spores. Host response involving phagocytic cells infiltrating into the hepatic parenchyma and frequently containing spores. Scale bar $=50 \mu \mathrm{m}$. (B) Enlarged macrophage aggregation in the liver containing moderate numbers of $S$. destruens. Scale bar $=50 \mu \mathrm{m}$. (C) $S$. destruens in the connective tissue and vessels posterior to the retina. S. destruens cells associated with melanomacrophages and giant cells (arrow). Scale bar $=100 \mu \mathrm{m}$. (D) Small focus of inflammatory tissue associated with $S$. destruens cells between muscle fibres. Scale bar $=100 \mu \mathrm{m}$

osmiophilic lipoid material which was Gram-positive (Figs. 2A \& 4B,C). The cytoplasm also contained large numbers of ribosomes, isolated strands of endoplasmic reticulum and membrane-bound vesicular structures (Fig. $4 \mathrm{~B}, \mathrm{D})$ which occasionally contained several microvesicles. Spores were bounded by an inner trilaminar plasma membrane coated by a dense, finely granular layer (presumably of parasite origin) and were separated from the host cell cytoplasm by an intermediate amorphous region and another electron-dense layer with a further membrane that appears to be of host cell origin (Fig. 3D).

\section{DISCUSSION}

Here, we report the first description of Sphaerothecum destruens infection in a wild cyprinid population with a natural prevalence of $2.2 \%$ (detected by PCR) in Leucaspius delineatus. Previously, the prevalence of
S. destruens in wild populations has been reported from only a single survey of the late autumn run of Oncorhynchus tshawytscha from the Sacramento River, California, USA, where a $32 \%$ prevalence of $S$. destruens was detected (Arkush et al. 1998). However, in captive $O$. tshawytscha broodstock, the prevalence of infection ranged from 0.7 to $40.1 \%$ within a $3 \mathrm{yr}$ period (Arkush et al. 1998). In laboratory experiments, detection of $S$. destruens in $L$. delineatus by PCR reached $28 \%$ in non-moribund fish (Gozlan et al. 2005).

Histological examination of Leucaspius delineatus revealed forms of disease similar to the disseminated and nodular forms of infection reported from salmonids. However, the disseminated form appeared to be the most common form of disease in $L$. delineatus. There were differences in Sphaerothecum destruens pathology in $L$. delineatus compared to that seen in Oncorhynchus tshawytscha; these differences included the presence of $S$. destruens spores within giant 

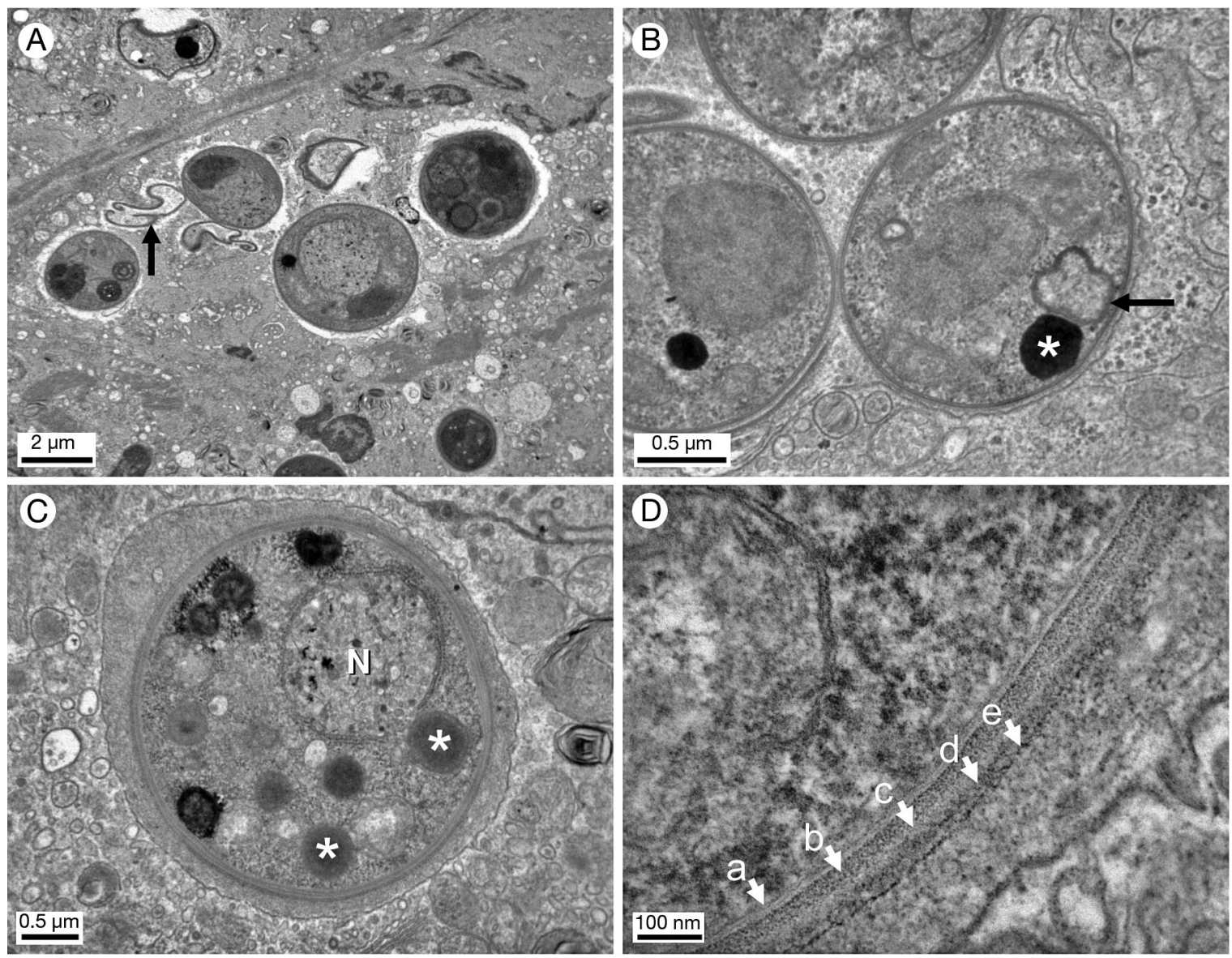

Fig. 4. Leucaspius delineatus. Electron micrographs of tissue infected with Sphaerothecum destruens. (A) Intracellular stages of $S$. destruens in the granulomatous tissue of sunbleak kidney. Note the presence of necrotic $S$. destruens with loss of cellular contents and folding of the cell wall (arrow). Scale bar $=2 \mu \mathrm{m}$. (B) Cluster of $3 S$. destruens spores showing the characteristic granular cytoplasm with densely osmiophilic structures (*) and vesicular structure (arrow). Scale bar $=0.5 \mu \mathrm{m}$. (C) An isolated $S$. destruens spore located intracellularly within a phagocyte. The nucleus $(\mathrm{N})$ in this case is pale-staining with conspicuous electron-dense granules. Note the presence of multiple lipoid inclusions $(*)$ and membrane-bound vesicular structures. Scale bar $=0.5 \mu$ m. (D) High-power view of the spore wall of $S$. destruens. Inner trilaminar plasma membrane (a) coated by a dense finely granular layer (b) and separated from the host cell's cytoplasm by an intermediate amorphous region (c) and another electron-dense layer (d) with a further membrane that appears to be of host cell origin (e). Scale bar $=100 \mathrm{~nm}$

cells, and the presence of only the smaller spore morphotype $(2$ to $4 \mu \mathrm{m})$. In the disseminated form, $S$. destruens spores were often associated with the proliferation of connective tissue. This was observed in all organs. It has been suggested that the disseminated form of the disease, and the lack of host response, are indicative of fish which are more susceptible to the disease (Hedrick et al. 1989, Arkush et al. 1998). Individual variations in resistance to $S$. destruens could explain the 2 forms of the disease reported in L. delineatus. However, these may represent different stages of the disease. In some cases both forms of the disease have been observed within the same individual. If the disease were allowed to progress, the formation of granulomas in organs displaying pathology similar to the disseminated form would appear likely.
In the current study the kidney was the most severely affected organ, displaying serositis surrounding the organ as well as inflammation surrounding parasitized tubules. The presence of focal aggregates of Sphaerothecum destruens, i.e. rosettes, was usually associated with cell necrosis, supporting the view that host cell death results from intracellular parasitism (Arkush et al. 1998). In addition, the detection of $S$. destruens within the lumina and epithelia of renal tubules, and the intestinal tract, provides further support to the hypothesis that parasite excretion occurs through the urine and shedding of the gut epithelium (Arkush et al. 2003). The ultrastructural characteristics of $S$. destruens in Leucapsius delineatus were similar to those reported from salmonid infections. The cytoplasm contained dense osmiophilic lipoid material 
which was Gram-positive. As in salmonid tissues, $S$. destruens was often detected in the cytoplasm of macrophages (Arkush et al. 1998).

Within the population sampled, the presence of only a few, heavily infected fish suggests that Sphaerothecum destruens infections are over-dispersed. In histological sections, the use of Gram's stain is valuable for detecting moderate infections; however, low-level infections may remain undetected. Consequently, an increased number of fish will need to be sampled in order to have a high probability of histologically detecting the disease. PCR amplification of $S$. destruens DNA alone does not infer infection in the fish, or parasite viability, but this approach can be used alongside histological evaluation to facilitate epizootiogical studies. PCR is more cost- and time-effective, and it can be used as an initial screen of large numbers of individuals for $S$. destruens DNA (Cunningham 2002, Mendonca \& Arkush 2004); this can be followed up for evidence of parasite viability and pathogenicity using histological methods.

The origin and source of the infection in Leucapsius delineatus is currently unknown (Gozlan et al. 2009), but the recent association with Pseudorasbora parva (Gozlan et al. 2005, Andreou et al. 2011), the most invasive fish species in Europe (Gozlan et al. 2010), represents a major risk for the spread of the disease within Europe and beyond, with direct implications for salmonid aquaculture and recreational fisheries (Gozlan et al. 2006, Peeler et al. 2011). This is largely due to the lack of long-term data on the parasite composition populations of different species. The identification of naturally occurring Sphaerothecum destruens infections in $L$. delineatus adds this species to the host range and provides evidence of a potential host switch for $S$. destruens in the wild.

Acknowledgements. This work was supported by the UK Department for Environment, Food and Rural Affairs (contracts FC1176 and FB001).

\section{LITERATURE CITED}

Andreou D (2010) Sphaerothecum destruens: life history traits and host range. PhD dissertation, Cardiff University, Cardiff

Andreou D, Gozlan RE, Paley R (2009) Temperature influence on production and longevity of Sphaerothecum destruens zoospores. J Parasitol 95:1539-1541

Andreou D, Hussey M, Griffiths SW, Gozlan RE (2011) Influence of host reproductive state on Sphaerothecum destruens prevalence and infection level. Parasitology 138:26-34

Editorial responsibility: David Bruno,

Aberdeen, UK
Arkush KD, Frasca S, Hedrick RP (1998) Pathology associated with the rosette agent, a systemic protist infecting salmonid fishes. J Aquat Anim Health 10:1-11

Arkush KD, Mendoza L, Adkinson MA, Hedrick RP (2003) Observations on the life stages of Sphaerothecum destruens n. g., n. sp., a mesomycetozoean fish pathogen formally referred to as the rosette agent. J Eukaryot Microbiol 50:430-438

> Bucke D, Feist SW, Clifton-Hadley RS (1991) The occurrence of proliferative kidney disease (PKD) in cultured and wild fish: further investigations. J Fish Dis 14:583-588

Cunningham CO (2002) Molecular diagnosis of fish and shellfish diseases: present status and potential use in disease control. Aquaculture 206:19-55

Elston RA, Harrell L, Wilkinson MT (1986) Isolation and in vitro characteristics of Chinook salmon (Oncorhynchus tshawytscha) rosette agent. Aquaculture 56:1-21

Feist SW, Longshaw M (2008) Histopathology of fish parasite infections -importance for populations. J Fish Biol 73: $2143-2160$

Freyhof J, Kottelat M (2008) Leucaspius delineatus. IUCN Red List of Threatened Species. www.iucnredlist.org (accessed 2 Jun 2011)

Gozlan RE, Pinder AC, Durand S, Bass J (2003) Could the small size of sunbleak, Leucaspius delineatus (Pisces, Cyprinidae) be an ecological advantage in invading British waterbodies? Folia Zool 52:99-108

Gozlan RE, St-Hilaire S, Feist SW, Martin P, Kent ML (2005) Biodiversity - disease threat to European fish. Nature 435:1046

Gozlan RE, St-Hilaire S, Feist SW, Longshaw M, Peeler EJ (2006) The effect of microbial pathogens on the diversity of aquatic populations, notably in Europe. Microbes Infect 8:1358-1364

Gozlan RE, Whipps C, Andreou D, Arkush K (2009) Identification of a rosette-like agent as Sphaerothecum destruens, a multi-host fish pathogen. Int J Parasitol 39:1055-1058

Gozlan RE, Andreou D, Asaeda T, Beyer K and others (2010) Pan-continental invasion of Pseudorasbora parva: towards a better understanding of freshwater fish invasions. Fish Fish 11:315-340

Harrell LW, Elston RA, Scott TM, Wilkinson MT (1986) A significant new systemic disease of net-pen reared Chinook salmon (Oncorhynchus tshawytscha) brood stock. Aquaculture 55:249-262

Hedrick RP, Friedman CS, Modin J (1989) Systemic infection in Atlantic salmon Salmo salar with a Dermocystidiumlike species. Dis Aquat Org 7:171-177

Mendonca HL, Arkush KD (2004) Development of PCR-based methods for detection of Sphaerothecum destruens in fish tissues. Dis Aquat Org 61:187-197

Peeler EJ, Oidtmann BC, Midtlyng PM, Miossec L, Gozlan RE (2011) Non-native aquatic animals introductions have driven disease emergence in Europe. Biol Invas 13(6): 1291-1303

Reynolds ES (1963) The use of lead citrate at high $\mathrm{pH}$ as an electron-opaque stain in electron microscopy. J Cell Biol 17:208-212

WCMC (World Conservation Monitoring Centre) (1996) Leucaspius delineatus. IUCN Red List of Threatened Species. www.iucnredlist.org (accessed 21 Sep 2007)

Submitted: November 25, 2010; Accepted: March 9, 2011 Proofs received from author(s): June 6, 2011 